\title{
Cosolvent Selection for Supercritical Fluid Extraction (SFE) of Bioactive Compounds from Orthosiphon stamineus
}

(Pemilihan Kopelarut Bagi Pengekstrakan Bendalir Lampau Genting (SFE)

Sebatian Bioaktif Daripada Orthosiphon stamineus)

\author{
MASNIZA MOHAMED@MAHMOOD, WAN RAMLi WAN DAUD, MASTURAH MARKOM* \\ \& CHE NURUl Ain NADIRAH CHE MANSOR
}

\begin{abstract}
In this work, a preliminary study was conducted to study the effects of different types and concentrations of cosolvents based on the total yield and antioxidants capacity prior to supercritical fluid extraction (SFE) of Orthosiphon stamineus (locally referred as misai kucing). Initially, a comparison was made by cold maceration technique with nine types of different cosolvents, namely water, pure ethanol, $25 \%(\mathrm{v} / \mathrm{v})$ of ethanol in water, $50 \%(\mathrm{v} / \mathrm{v})$ of ethanol in water, $75 \%(\mathrm{v} / \mathrm{v})$ of ethanol in water, pure methanol, $25 \%(\mathrm{v} / \mathrm{v})$ of methanol in water, $50 \%(\mathrm{v} / \mathrm{v})$ of methanol in water and $75 \%(\mathrm{v} / \mathrm{v})$ of methanol in water. The antioxidant capacity was analysed by free radical scavenging activity of 2,2-diphenyl-1-picrylhydrazyl (DPPH), total phenolic content (TPC) and total flavonoid content (TFC). Aqueous ethanolic solvent of $50 \%(\mathrm{v} / \mathrm{v})$ ethanol in water showed the highest total yield of extract of $4.64 \pm 0.02 \%$. All antioxidant assays of TPC and TFC showed the highest

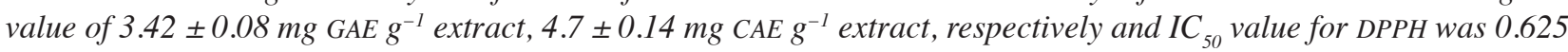
$\mu \mathrm{g} / \mathrm{mL}$ for $50 \%(\mathrm{v} / \mathrm{v})$ ethanol in water extract. Based on the overall result, ethanolic solvents gave a better result for all antioxidant assays compared to those of methanolic solvents. Using the selected cosolvent, the identification of target compounds, which were rosmarinic acid, eupatorin and sinensetin from supercritical fluid extraction was determined by using HPLC. In conclusion, ethanol-water solvent was efficient in extracting bioactive compounds in O. stamineus and also improved the total yield, thus the usage of ethanolic solvent in different concentrations should be considered for further optimisation of SFE with cosolvent studies.
\end{abstract}

Keywords: High pressure extraction; Orthosiphon stamineus; supercritical fluid extraction

ABSTRAK

Kajian awal dijalankan untuk mengkaji kesan jenis dan kepekatan kopelarut berbeza berdasarkan hasil ekstrak dan kapasiti antioksidan untuk pengekstrakan Orthosiphon stamineus (misai kucing) menggunakan pengekstrakan bendalir lampau genting (SFE). Perbandingan dibuat oleh teknik maserasi menggunakan sembilan jenis kopelarut yang berbeza iaitu air, etanol tulen, $25 \%(\mathrm{v} / \mathrm{v})$ etanol dalam air, 50\% (v/v) etanol dalam air, $75 \%(\mathrm{v} / \mathrm{v})$ etanol dalam air, metanol tulen, 25\% (v/v) metanol dalam air, $50 \%(\mathrm{v} / \mathrm{v})$ metanol dalam air dan 75\% (v/v) metanol dalam air. Kapasiti antioksidan ditentukan oleh aktiviti perencatan radikal bebas 2,2-diphenyl-1-picrylhydrazyl (DPPH), jumlah kandungan fenolik (TPC) dan jumlah kandungan flavonoid (TFC). Pelarut etanol akueus $50 \%$ (v/v) etanol dalam air menunjukkan hasil tertinggi ekstrak iaitu $4.64 \pm 0.02 \%$. Semua ujian antioksidan TPC dan TFC, masing-masing

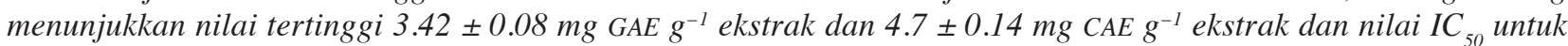
DPPH ialah $0.625 \mu \mathrm{g} / \mathrm{mL}$ untuk ekstrak 50\% (v/v) etanol dalam air. Berdasarkan hasil keseluruhan, pelarut etanol memberikan hasil yang lebih baik untuk semua ujian cerakin antioksidan berbanding hasil daripada pelarut metanol. Kajian selanjutnya untuk pengenalpastian sebatian sasaran asid rosmarinic, eupatorin dan sinensetin menggunakan kopelarut terbaik yang dipilih daripada pengekstrakan bendalir lampau genting (SFE) ditentukan dengan menggunakan HPLC. Kesimpulannya, larutan etanol akueus adalah lebih cekap dalam mengekstrak sebatian bioaktif dalam O. stamineus dan juga meningkatkan jumlah hasil, oleh itu penggunaan pelarut etanol dalam kepekatan yang berbeza harus dipertimbangkan untuk pengoptimuman SFE dengan kopelarut.

Kata kunci: Pengekstrakan bendalir lampau genting; pengekstrakan tekanan tinggi; Orthosiphon stamineus

\section{INTRODUCTION}

Orthosiphon stamineus or misai kucing is a herbal plant belongs to a genus in the family of Lamiaceae. It is a popular folk medicine broadly used in Southeast Asia for the treatment of wide range of diseases and in Malaysia, the tea made from $O$. stamineus leaves is consumed as a beverage to improve health and to treat various diseases such as kidney disorders, bladder inflammation, gout, diabetes, eruptive fevers, hepatitis, hypertension, syphilis, rheumatism, gonorrhoea and diuretic (Akowuah et al. 
2004; Ameer et al. 2012; Ho et al. 2010). This herb has various terpenoids, polyphenols and sterols (Tezuka et al. 2000), leading to medicinal benefits such as antibacterial, antifungal, antimicrobial and antitumor and exhibits antioxidant and anticancer activities (Akowuah et al. 2004; Ameer et al. 2012; Scheckel et al. 2008; Yam et al. 2009). Previous studies reported that $O$. stamineus leaves contain high contents of phenolic compounds including lipophilic flavones, caffeic acid derivatives, rosmarinic acid, 2,3-dicaffeoyltartaric acid (Akowuah et al.2004) and flavonoids such as sinensetin, eupatorin and 3'-hydroxy-5,6,7,4' - tetramethoxyflavone (Ameer et al. 2012; Muhammad et al. 2011; Yam et al. 2009).

In order to extract all bioactive compounds from this valuable herb, numerous studies have been conducted in recent years. However, the major concern for both researchers and pharmaceutical companies when dealing with herbs extraction is the effect of the extraction process on the nutritional or bioactive components, toxicity and solvent residue (Al-Suede et al. 2014). Nowadays, the conventional methods available for herb extractions are steam distillation, hydro distillation and solvent extraction. In fact, solvent extraction has been commonly used to extract bioactive compounds from plants (Musa et al.2011), nevertheless this method is time consuming and requires the usage of harmful solvents. Al-Suede et al. (2014) suggested that O. stamineus tea prepared using bioactive compounds extracted from an economical and environmentally friendly supercritical fluid could be a valuable bio-resource with anticancer potential against prostate malignancy. Using $\mathrm{CO}_{2}$ in SFE is good as it ensures minimal modification of the bioactive compounds and thereby preserving the native chemical properties of the compounds and thus the curative and functional properties of the compounds will be retained (Cavero et al. 2006).

Supercritical fluid extraction (SFE) is found worthwhile in the extraction of natural products due to the lower temperature operations, reduced solvent consumption and shorter extraction times compared to the conventional methods. Improved yield and selectivity of useful products can be achieved by only a change in pressure and temperature or can be done by a cosolvent combination, thus avoiding the usage of harmful solvent and reducing the fractionation steps required (Markom 2007). The stability of different extracts from the same material depends on the extraction solvent used for the removal of the polyphenolic compounds and it is apparent that the extracts from the same plant may vary widely with respect to their antioxidant concentrations and activities (Akowuah et al. 2004). However, to the best of our knowledge, cosolvent selection in supercritical fluid extraction of bioactive compounds from $O$. stamineus has not been reported. In this study, the effects of different types and concentrations of cosolvent on the total yield and capacity of antioxidants prior to supercritical fluid extraction (SFE) of O. stamineus were investigated.

\section{MATERIALS AND METHODS}

\section{SAMPLE PREPARATION}

Dried leaves of misai kucing (Orthosiphon stamineus) were purchased from a local supplier (Herbagus, Penang Malaysia). The moisture content of the leaves was $11.93 \%$ (dry basis) and it was determined using Sartorious moisture analyser. The samples were ground into $0.5 \mathrm{~mm}$ particle size and packaged into a nylon-liner low density polyethylene pouch covered with aluminium foil upon the arrival at the laboratory. The samples were kept in a dark environment at room temperature until used.

\section{SOLVENT EXTRACTION}

One gram of $O$. stamineus powder was accurately weighed and immersed into $25 \mathrm{~mL}$ glass bottles containing $20 \mathrm{~mL}$ of different solvents. Nine types of different solvents used were water, pure ethanol, $25 \%(\mathrm{v} / \mathrm{v})$ of ethanol in water, $50 \%(\mathrm{v} / \mathrm{v})$ of ethanol in water, $75 \%(\mathrm{v} / \mathrm{v})$ of ethanol in water, pure methanol, $25 \%$ (v/v) of methanol in water, $50 \%$ $(\mathrm{v} / \mathrm{v})$ of methanol in water and $75 \%(\mathrm{v} / \mathrm{v})$ of methanol in water and the ratio was 1:20. The bottles were then sealed with parafilm and wrapped with aluminium foil to prevent spillage and light exposure, respectively. The mixtures were left at dark environment for three days and then the extracts were filtered using Whatman No. 1 filter paper. Crude extracts were collected after the sample underwent drying process in an oven at $45^{\circ} \mathrm{C}$ overnight. All the extractions were conducted in replicates. The extraction yields of all extracts were calculated using the following equation:

$$
\text { Total extract yield }(\%)=\frac{\text { Total mass of extract }}{\text { Total mass of sample }} \times 100 \%
$$

\section{SUPERCRITICAL FLUID EXTRACTION}

Supercritical fluid extraction (SFE) system comprises of a carbon dioxide pump (PU-2080, JASCO Corporation, Japan), series 111 solvent pump (Lab Alliance, USA), BP 1580-81 model back pressure regulator (BPR, JASCO Corporation, Japan), extractor vessel enclosed in a FX2-2 model air circulating oven (Sheldon Manufacturing, USA), pressure transmitter (model 682-8, Dwyer Instrument, USA) and sample collector. A chiller (Protech Electronic, Malaysia) was used to retain the liquid state of the liquefied carbon dioxide at $-4^{\circ} \mathrm{C}$ before the extraction process started.

The extraction was performed at fixed conditions. The flow rates for liquid $\mathrm{CO}_{2}$ were fixed at $4 \mathrm{~mL} / \mathrm{min}, 60^{\circ} \mathrm{C}$, 225 bar and using $10 \%(\mathrm{v} / \mathrm{v})$ of $50 \%(\mathrm{v} / \mathrm{v})$ ethanol in water (cosolvent). Five grams of $( \pm 0.05) O$. stamineus samples were placed into the extractor vessel and the extraction started by dynamic extraction mode and each fraction was collected every $30 \mathrm{~min}$. Each fraction was dried in an oven at $45^{\circ} \mathrm{C}$ and the dried extracts were kept in $-20^{\circ} \mathrm{C}$ before undergoing further analysis. 


\section{DETERMINATION OF ANTIOXIDANT CONTENT}

Determination of Free Radical Scavenging Activity The ability of $O$. stamineus to scavenge 2,2-diphenyl-1picrylhydrazyl (DPPH) was determined by the DPPH free radical scavenging activity assay. The scavenging effects were determined based on the method of previous study with slight modifications (Hafizah et al. 2014). The 0.1 $\mathrm{mM}$ of DPPH solution was prepared by diluting $1 \mathrm{mg}$ of DPPH in $25 \mathrm{~mL}$ of ethanol. Each $O$. stamineus extract with nine different solvents $(100,200,300,400$ and $500 \mu \mathrm{g} /$ $\mathrm{mL}$ ) was prepared. A mixture of $200 \mu \mathrm{L}$ of DPPH and $50 \mu \mathrm{L}$ of each extract was transferred into a 96-well microplate. The mixtures were sealed with parafilm and shaken for 2 min in order to mix the solution. The mixtures were then left in a dark room for $30 \mathrm{~min}$ for incubation before reading the absorbance at $517 \mathrm{~nm}$ using a microplate reader. The blank samples were $200 \mu \mathrm{L}$ of $0.1 \mathrm{mM}$ of DPPH and $50 \mu \mathrm{L}$ of each solvent type. Ascorbic acid and BHT were used as positive controls. All samples were in triplicates. The ability of extracts and positive controls to scavenge free radical was calculated using the following formula:

$$
I \%=\left[\left(A_{\text {blank }}-A_{\text {sample }}\right) / A_{\text {blank }}\right] \times 100 \%
$$

$\mathrm{A}_{\text {blank }}$ is the absorbance of $0.1 \mathrm{mM}$ of DPPH with ethanol and $\mathrm{A}_{\text {sample }}$ is the absorbance of the $O$. stamineus extracts and positive controls solutions. All results were interpreted by $\mathrm{IC}_{50}$ value. The $\mathrm{IC}_{50}$ value is the ability to scavenge at $50 \%$ of DPPH free radical.

Determination of Total Phenolic Content (TPC) The total phenolic content which used Folin-Ciocalteu reagent was determined using a slightly modified version of the standard method (Hassim et al. 2014). The extract was prepared at a concentration of $1 \mathrm{mg} / \mathrm{L}$. Approximately 20 $\mu \mathrm{L}$ of extract was transferred into a 96-well microplate and $100 \mu \mathrm{L}$ of Folin-Ciocalteu reagent (previously diluted tenfold with distilled water) was added and mixed. The mixture was allowed to stand at room temperature for 7 $\min$. About $80 \mu \mathrm{L}$ of $7.5 \%(\mathrm{v} / \mathrm{v})$ of sodium carbonate was added to the mixture and mixed gently. After standing at room temperature for $2 \mathrm{~h}$, the absorbance was read at 725 $\mathrm{nm}$ using a microplate reader. The standard calibration (20, 40, 60 and $80 \mathrm{mg} / \mathrm{L}$ of gallic acid) curve was plotted. The total phenolic content was expressed as gallic acid equivalents (GAE) $\mathrm{g}^{-1}$ of extract. All experiments were performed in triplicates.

Determination of Total Flavonoid Content (TFC) The total flavonoid content of the crude extract was determined by the calorimetric assay method (Jia et al. 1999) with modifications in the volume and equipment used. In brief, $20 \mu \mathrm{L}$ of diluted extract $(1 \mathrm{mg} / \mathrm{mL}$ of distilled water $)$ was mixed with $80 \mu \mathrm{L}$ of distilled water and then $6 \mu \mathrm{L}$ of $5 \%$ $(\mathrm{w} / \mathrm{v})$ of $\mathrm{NaNO}_{2}$ solution. About $6 \mu \mathrm{L}$ of $10 \%(\mathrm{w} / \mathrm{v})$ of $\mathrm{AlCl}_{3}$ solution was added after $5 \mathrm{~min}$ of incubation and the mixture was allowed to stand for $6 \mathrm{~min}$. Then, $40 \mu \mathrm{L}$ of 1 $\mathrm{M}$ of the $\mathrm{NaOH}$ solution was added and the final volume of the mixture was brought to $200 \mu \mathrm{L}$ with distilled water. The mixture was allowed to stand for $15 \mathrm{~min}$ and the absorbance was measured at $510 \mathrm{~nm}$. The total flavonoid content was calculated from a calibration curve and the result was expressed on a fresh weight basis as catechin equivalents (CEQ) $\mathrm{g}^{-1}$ extract.

\section{HPLC ANALYSIS}

Analyses were performed on a high performance liquid chromatography (HPLC, model 2998, Waters Corporation, USA) equipped with an autosampler and a photodiode array detector. The column used was a reverse phase $\mathrm{C} 18$, Chromolith (i.d. $100 \times 4.6 \times 5 \mathrm{~mm}$ ). An acetonitrile/water/ triflouroacetic acid mobile phase system was used for the chromatographic separation. In this study, the identification of bioactive compounds was carried out by comparing HPLC retention time of rosmarinic acid, eupatorin and sinensetin standards. The improvement of extraction efficiency by SFE using the selected cosolvent method was confirmed by chromatogram of the plant extract.

\section{RESULTS AND DISCUSSION}

\section{SOLVENT EFFECTS ON EXTRACT YIELD}

Figure 1 and Table 1 show the extract yields of different cosolvents. The highest extracted yield was obtained from $50 \%(\mathrm{v} / \mathrm{v})$ ethanol in water which was $4.64 \pm 0.02 \%$. The results indicate that there were no significant different $(p>005)$ between the yield obtained from ethanolic solvent and methanolic solvent $(4.52 \pm 0.02 \%)$. Water extract gave a comparable yield of $4.32 \pm 0.03 \%$ which indicates that polar compounds are easier to be extracted compared to nonpolar compounds. Water, methanol and ethanol contain hydroxyl group which can form a hydrogen bonding with the solute, but water has shorter chain and higher polarity making it more effective in extracting the solute (Pin et al. 2010; Razak et al. 2012). Thus, the addition of water in the organic solvent increased the extraction yield for both ethanolic and methanolic solvent. The lowest extract was achieved by the extraction using methanol at $2.85 \pm 0.01 \%$. This is due to the variation in solubility and polarity of both component and solvent. Razak et al. (2012) also reported that the extraction of $O$. stamineus gave the highest yield using water (34\%) followed by ethanol $(5 \%)$. It was stated that rosmarinic acid is present in $O$. stamineus abundantly of which it extraction is favoured by very polar solvents. The addition of polar modifier could increase the solubility of a less soluble solute in the solvent mixtures, which results in the improvement of extraction efficiency (Azfar et al. 2014). Markom (2007) proved that by adding water in acetone and ethanol increased the yield of Phyllanthus niruri extracts due to the coextraction of less polar and polar compounds. 


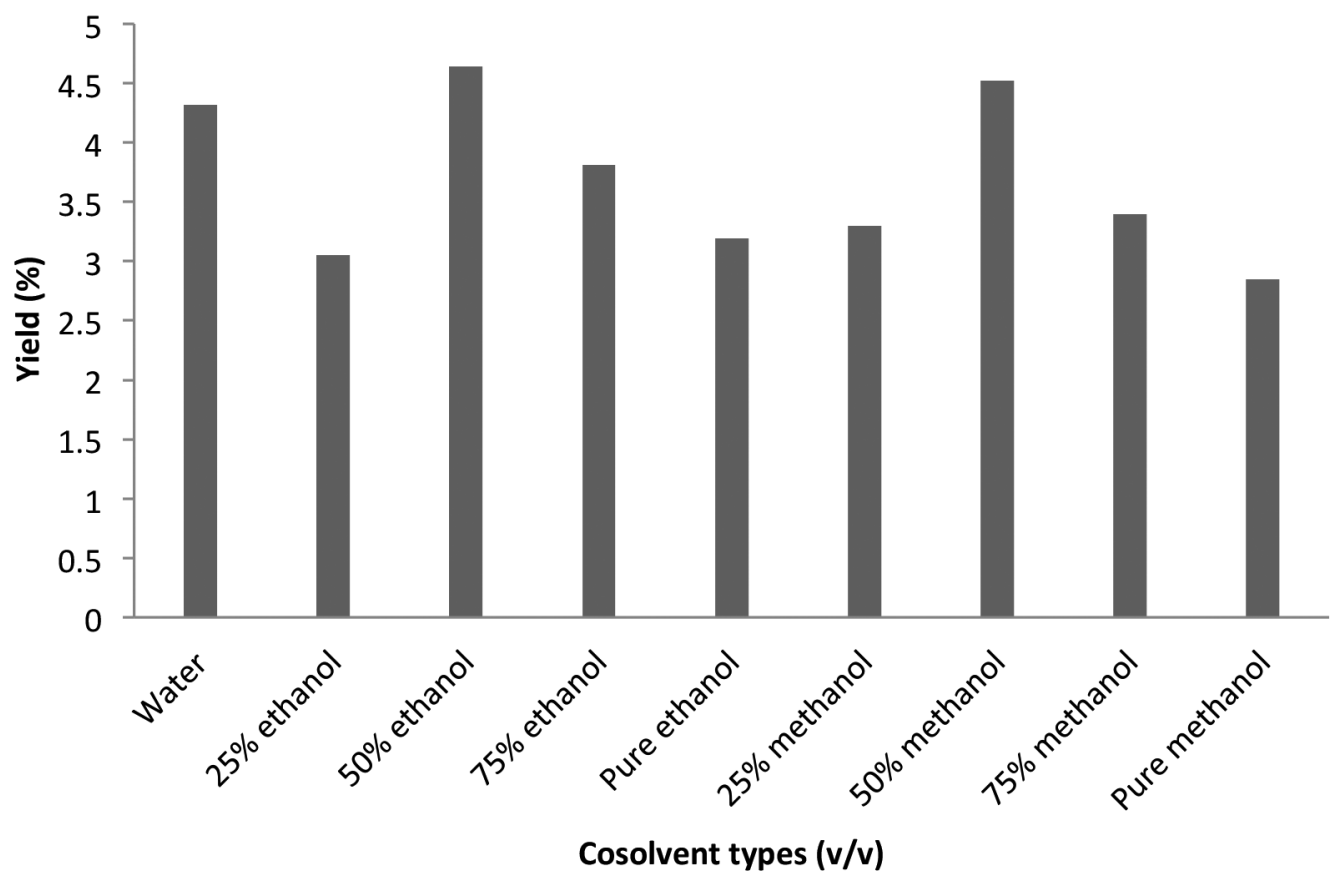

FIGURE 1. Extract yield obtained from cold maceration extraction using different cosolvent types and concentrations

TABLE 1. Percentage yield of solvents extracts

\begin{tabular}{lc}
\hline Cosolvent types $(\mathrm{v} / \mathrm{v})$ & Yield $(\%)$ \\
\hline water & $4.32 \pm 0.03^{\mathrm{ab}}$ \\
pure ethanol & $3.19 \pm 0.08^{\mathrm{bc}}$ \\
$25 \%$ ethanol & $3.05 \pm 0.16^{\mathrm{c}}$ \\
$50 \%$ ethanol & $4.64 \pm 0.02^{\mathrm{a}}$ \\
$75 \%$ ethanol & $3.81 \pm 0.15^{\mathrm{abc}}$ \\
Pure methanol & $2.85 \pm 0.01^{\mathrm{c}}$ \\
$25 \%$ methanol & $3.3 \pm 0.14^{\mathrm{c}}$ \\
$50 \%$ methanol & $4.52 \pm 0.01^{\mathrm{a}}$ \\
$75 \%$ methanol & $3.4 \pm 0.14^{\mathrm{bc}}$ \\
\hline
\end{tabular}

Percentage yield of solvent extracts $(n=3)^{*}$. Means that do not share a letter are significantly different $(p<0.05)$. (a)-Highest yield and significantly different from other yields $(a b, c, b c \& a b c)$.*Replication of extractions

\section{SOLVENT EFFECTS ON ANTIOXIDANT ACTIVITY}

DPPH, TPC and TFC were evaluated for antioxidant activity. The results showed that in comparison to individual assay, $50 \%(\mathrm{v} / \mathrm{v})$ ethanol in water showed good antioxidant activities in all the assays tested. This finding is similar to the result obtained by Kamarudin et al. (2015).

Table 2 shows the TPC for the ethanolic extract were ranged from $1.78 \pm 0.13$ to $3.42 \pm 0.08 \mathrm{mg} / \mathrm{g} \mathrm{GAE}$ and the TPC for the methanolic extract were between $1.76 \pm 0.08$ and $3.00 \pm 0.12 \mathrm{mg} \mathrm{GAE}^{-1}$ extract. The extraction using $50 \%(\mathrm{v} / \mathrm{v})$ of ethanol in water showed the maximum TPC. The polarity of the solvents used to extract polyphenols from plant materials might cause the variation in TPC values (Alshawsh et al.2011). From the result, TFC values showed a similar trend with TPC where the highest value calculated was obtained by the extraction using $50 \%(\mathrm{v} / \mathrm{v})$

TABLE 2. Antioxidant capability of solvents extracts

\begin{tabular}{ccc}
\hline Cosolvent types $(\mathrm{v} / \mathrm{v})$ & TPC $\left(\mathrm{mg} \mathrm{GAE} \mathrm{g}^{-1}\right.$ extract $)$ & TFC $\left(\mathrm{mg} \mathrm{CAE} \mathrm{g}^{-1}\right.$ extract $)$ \\
\hline water & $1.90 \pm 0.05$ & $1.77 \pm 0.29$ \\
pure ethanol & $1.78 \pm 0.13$ & $0.32 \pm 0.02$ \\
$25 \%$ ethanol & $2.30 \pm 0.03$ & $3.0 \pm 0.04$ \\
$50 \%$ ethanol & $3.42 \pm 0.08$ & $4.7 \pm 0.14$ \\
$75 \%$ ethanol & $2.98 \pm 0.13$ & $4.63 \pm 0.10$ \\
pure methanol & $1.76 \pm 0.08$ & $0.17 \pm 0.0$ \\
$25 \%$ methanol & $2.07 \pm 0.12$ & $1.50 \pm 0.01$ \\
$50 \%$ methanol & $2.93 \pm 0.04$ & $3.79 \pm 0.12$ \\
$75 \%$ methanol & $3.00 \pm 0.12$ & $4.5 \pm 0.00$ \\
\hline
\end{tabular}




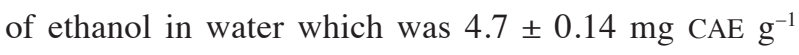
extract. It can be deduced that the total flavonoid are the important phenolic compounds in O. stamineus. Akowuah et al. (2004) reported that apart from the phenolic compounds, other compounds present in O. stamineus such as ursolic, oleanolic and betulinic acids might also contribute to the antioxidant activity in the extract. On the other hand, a high yield of phenolic compounds does not necessarily come with high antioxidant capacity, as the antioxidant activity of crude extract might also be related to the structure and interaction between the extracted phenolic compounds (Huang et al. 2005).

The overall results showed that $O$. stamineus exhibited a high antioxidant activity by its scavenging activity towards DPPH radicals. The results indicated that all solvent types gave a better range of $\mathrm{IC}_{50}$ values compared to those of the synthetic antioxidant, BHT. However, the ethanolic solvents gave a better result among all the solvents studied. As can be seen in Table 3 , the $\mathrm{IC}_{50}$ value of the $50 \%(\mathrm{v} / \mathrm{v})$ ethanol extract $(0.625 \pm 0.10 \mu \mathrm{g} / \mathrm{mL})$ was better than that of the synthetic antioxidant compound BHT (8.845 \pm 0.03 $\mu \mathrm{g} / \mathrm{mL}$ ) but still higher than the natural antioxidant, ascorbic acid $(0.468 \pm 0.01 \mu \mathrm{g} / \mathrm{mL})$. Besides, the high antioxidant activity of $O$. stamineus which led to more potent radical scavenging effects is positively related to the high content of phenolic compound in it (Alshawsh et al. 2011).

\section{QUALITATIVE DETERMINATION OF ROSMARINIC ACID, EUPATORIN AND SINENSETIN FROM THE LEAVES OF O. STAMINEUS}

All samples from different solvent systems were analysed using HPLC. Figure 2 shows the HPLC chromatogram for the bioactive compounds of $O$. stamineus extracted using $50 \%$
TABLE 3. DPPH scavenging activity of $O$. stamineus extract and controls

\begin{tabular}{lc}
\hline Cosolvent types $(\mathrm{v} / \mathrm{v})$ & Concentration at $\mathrm{IC}_{50}(\mu \mathrm{m} / \mathrm{mL})$ \\
\hline water & 1.335 \\
pure ethanol & 1.588 \\
$25 \%$ ethanol & 0.692 \\
$50 \%$ ethanol & 0.625 \\
$75 \%$ ethanol & 0.641 \\
Pure methanol & 1.243 \\
$25 \%$ methanol & 0.722 \\
$50 \%$ methanol & 0.635 \\
$75 \%$ methanol & 0.655 \\
Controls & \\
BHT & 8.845 \\
Ascorbic acid & 0.468 \\
\hline
\end{tabular}

$(\mathrm{v} / \mathrm{v})$ ethanol in water. The targeted bioactive compounds in $O$. stamineus extract such as rosmarinic acid, sinensetin and eupatorin were successfully detected at 8,19 and $21 \mathrm{~min}$ retention times, respectively. The presence of the bioactive compounds in the samples was proven by comparing the chromatogram of peak standards with the chromatogram of the separated components from the samples.

The HPLC profile of bioactive compounds of $O$. stamineus using SFE with $50 \%(\mathrm{v} / \mathrm{v})$ ethanol in water as cosolvent collected at $120 \mathrm{~min}$ is shown in Figure 2. In all samples during the supercritical fluid extraction, peaks for rosmarinic acid, sinensetin and eupatorin (phenolic compounds) were obtained in the chromatogram region between 9 and $21 \mathrm{~min}$, which can be concluded as the phenolic region for $O$. staminues extract. The phenolics contain in vivo antioxidant activities and have been used as natural antioxidants (Fuhrman et al. 1995).

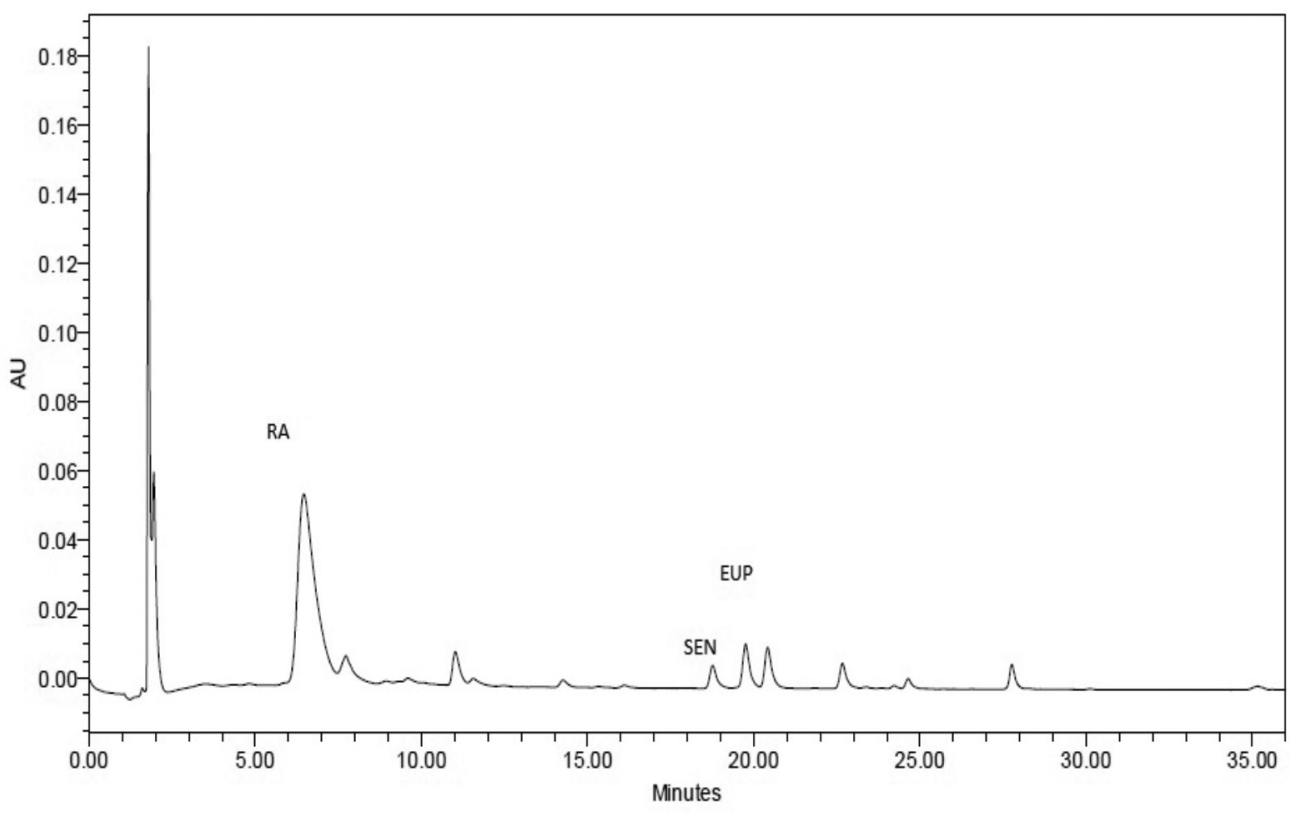

FIGURE 2. HPLC chromatogram on bioactive compounds of O.stamineus using 50\% (v/v) ethanol in water in solvent extraction 
Even though the qualitative analysis is only applicable to identify compounds, it was observed that a similar relation for both extraction methods. This kind of knowledge is very useful and can be applied for any possible alterations that might occur during the optimisation process later on.

\section{CONCLUSION}

In this study, the extraction using ethanolic cosolvents in water yielded the highest extract and also contributed to better antioxidants activities compared to those of the other solvents which were water and methanolic cosolvents in water. The highest total extract yield of $O$. stamineus was obtained using $50 \%(\mathrm{v} / \mathrm{v})$ ethanol in water as the extraction solvent. Total phenolic content (TPC) and total flavonoid (TFC) showed the same trend, as both were influenced by the type of solvents and their concentrations. DPPH $\mathrm{IC}_{50}$ value showed the antioxidant activity for the ethanolic extract was better than that of the methanolic extract, even though both values were in between their positive controls. Therefore, the SFE optimisation study with the selected ethanolic cosolvent in water should be further explored to determine the most efficient SFE with cosolvents extraction for O. stamineus .

\section{ACKNOWLEDGEMENTS}

The authors wish to gratefully acknowledge the financial support for this research by an Economic Transfer Program (ETP-2013-062) and GUP-2016-053.

\section{REFERENCES}

Akowuah, G.A., Zhari, I., Norhayati, I., Sadikun,A.\& Khamsah, S.M. 2004. Sinensetin, eupatorin, 3'-hydroxy-5,6,7,4'tetramethoxyflavone and rosmarinic acid contents and antioxidative effect of Orthosiphon stamineus from Malaysia. Food Chemistry 87: 569-666.

Alshawsh, M.A., Abdulla, M.A., Ismail, S. \& Amin, Z.A. 2011. Hepatoprotective effects of Orthosiphon stamineus extract on thioacetamide-induced liver cirrhosis in rats. EvidenceBased Complementary and Alternative Medicine doi: 10.1155/2011/103039.

Al-Suede, S.F.R., Ahamed, K.M., Aman, S., Majid, A., Aman, S., Baharetha, H.M., Hassan, L.E., Kadir, M.O.A., Nassar, Z.D., Majid, A. \& Amin, M.S. 2014. Optimization of cat's whiskers tea (Orthosiphon stamineus) using supercritical carbon dioxide and selective chemotherapeutic potential against prostate cancer cells. Evidence-Based Complementary and Alternative Medicine 2014: Article ID. 396016.

Ameer, O.Z., Salman, I.M., Asmawi, M.Z., Ibraheem, Z.O. \& Yam, M.F. 2012. Orthosiphon stamineus: Traditional uses, phytochemistry, pharmacology and toxicology: A review. Journal of Medicinal Food 15: 1-13.

Azfar, S.R., Badlishah Sham, B., Rashidi, O., Masturah, M. \& Russly, A.R. 2014. Co solvent selection for supercritical fluid extraction of astaxanthin and other carotenoids from penaeusmonodon waste. Journal of Oleo Science 63(8): 769-777.
Cavero, S., García-Risco, M.R., Marín, F.R., Jaime, L., Santoyo, S., Senoráns, F.J., Reglero, G. \& Ibanez, E. 2006. Supercritical fluid extraction of antioxidant compounds from oregano. Chemical and functional characterization via LCMS and in vitro assays. The Journal of Supercritical Fluids 38: 62-69.

Fuhrman, B., Lavy, A. \& Aviram, M. 1995. Consumption of red wine meal reduces the susceptibility of human plasma and low density lipoprotein to lipid. American Journal of Clinical Nutrition 61: 349-554.

Hafizah, M.H., Azizi, M.C.Y., Salman, Z. \& Fahim, R. 2014. The effects of solvents and extraction methods on the antioxidant activity of $P$. niruri. Jurnal Teknologi (Science \& Engineering) 68(5): 47-52.

Hassim, N., Markom, M., Anuar, N. \& Baharum, S.N. 2014. Solvent selection in extraction of essential oil and bioactive compounds from Polygonum minus. Journal of Applied Sciences 14(13): 1440-1444.

Ho, C.H., Ismail, N., Fariz, S. \& Ahmad, R. 2010. In vitro antibacterial and antioxidant activities of $O$. stamineus Benth extracts against food-borne bacteria. Food Chemistry 122: 1168-1172.

Huang, D., Ou, B. \& Prior, R.L. 2005. The chemistry behind antioxidant capacity. Journal of Agricultural and Food Chemistry 53(6): 1841-1856.

Musa, K.H., Abdullah, A., Jusoh, K. \& Subramaniam, V. 2011. Antioxidant activity of pink guava (Psidium guajava L.): Effect of extraction techniques and solvents. Food Analytical Methods 4: 100-107.

Markom, M. 2007. High pressure extraction and fractionation of tannins from Phyllanthus niruri Linn. PhD thesis. Kuala Lumpur, University of Malaya (Unpublished).

Muhammad, H., Carneiro, G.M.R., Poça, K.S., De-Oliveira, A.C., Afzan, A., Sulaiman, S.A., Ismail, Z. \& Paumgartten, F.J. 2011. Evaluation of the genotoxicity of Orthosiphon stamineus aqueous extract. Journal of Ethnopharmacology 27: 647-653.

Kamarudin, N.A., Markom, M. \& Latip, J. 2015. Effects of solvents and extraction methods on herbal plants Phyllanthus niruri, Orthosiphon stamineus and Labisa pumila. Jurnal Teknologi (Science \& Engineering) 72(1): 1-6.

Olah, N.K., Radu, L., Mogoşan, C., Hanganu, D. \& Gocan, S. 2003. Phytochemical and pharmacological studies on Orthosiphon stamineus benth. (Lamiaceae) hydroalcoholic extracts. Journal of Pharmaceutical and Biomedical Analysis 33(1): 117-123.

Pin, K.Y., Chuah, A.L., Rashih,A.A., Mazura, M.P., Fadzureena, J., Vimala, S. \& Rasadah, M.A. 2010. Antioxidant and antiinflammatory activities of extracts of betel leaves (Piper betle) from solvents with different polarities. Journal of Tropical Forest Science 22: 448-455.

Razak, A.M.F., Yong, P.K., Mad Shah, Z., Abdullah, L.C., Yee, S.S. \& Thomas, C.S.Y. 2012. The effects of varying solvent polarity on extraction yield of Orthosiphon stamineus leaves. Journal of Applied Science 12(11): 1207-1210.

Scheckel, K.A., Degner, S.C. \& Romagnolo, D.F. 2008. Rosmarinic acid antagonizes activator protein-1-dependent activation of cyclooxygenase- 2 expression in human cancer and non-malignant cell lines. Journal of Nutrition 138: 2098-2105.

Tezuka, Y., Stampoulis, P., Banskota, A., Awale, S., Tran, K., Saiki, I. \& Kadota, S. 2000. Constituents of the Vietnamese medicinal plant Orthosiphon stamineus. Chemical and Pharmceutical Bulletin (Tokyo) 48: 1711-1719. 
Yam, M.F., Ang, L.F., Basir, R., Salman, I.M., Ameer, O.Z. \& Asmawi, M.Z. 2009. Evaluation of the anti-pyretic potential of Orthosiphon stamineus Benth. standardized extract. Inflammopharmacology 17: 50-54.

Jia, Z.S., Tang, M.C. \& Wu, J.M. 1999. The determination of flavanoid contents in mulberry and their scavenging effects on superoxide radicals. Food Chemistry 64: 555-559.

Masniza Mohamed@Mahmood, Wan Ramli Wan Daud \& Masturah Markom*

Department of Chemical and Process Engineering Faculty of Engineering and Built Environment

Universiti Kebangsaan Malaysia

43600 UKM Bangi, Selangor Darul Ehsan

Malaysia

Che Nurul Ain Nadirah Che Mansor

School of Chemical Science and Food Technology

Faculty of Science and Technology

Universiti Kebangsaan Malaysia

43600 UKM Bangi, Selangor Darul Ehsan

Malaysia
Masniza Mohamed@Mahmood

Universiti Kuala Lumpur

Malaysian Institute of Chemical and Bioengineering Technology (MICET)

Lot 1988 Vendor City Taboh Naning

78000 Alor Gajah, Melaka

Malaysia

*Corresponding author; email: masturahmarkom@ukm.edu.my

Received: 15 September 2017

Accepted: 13 March 2018 